\title{
Review \\ Clinical review: Balancing the therapeutic, safety, and economic issues underlying effective antipseudomonal carbapenem use
}

Thomas G Slama

Department of Infectious Diseases, Indiana University School of Medicine, Indianapolis, Indiana 46260, USA

Corresponding author: Thomas G Slama, slamaidi@aol.com

Published: 29 October 2008

This article is online at http://ccforum.com/content/12/5/233

(c) 2008 BioMed Central Ltd
Critical Care 2008, 12:233 (doi:10.1186/cc6994)

units (ICUs), burn units, and extended care facilities where multiresistant organisms are frequently encountered. Empiric treatment to cover multiresistant pathogens may necessitate using regimens at the higher end of the dosage range; however, the use of such high doses may be problematic in practice. For imipenem, the dose-dependent risk of neurotoxicity and seizure adverse events has led to recommendations for caution in using high-dose regimens [1-4]. Similar concerns may apply to meropenem, which has also been associated with an increased seizure risk [3,5-7]. Higher doses of carbapenems generally come at higher acquisition costs, while use of lower doses may increase the risk of treatment failure. Furthermore, suboptimal dosing is a well known driver for the development of antibiotic resistance during antibiotic therapy [8]. Appropriate dosing therefore presents a serious therapeutic dilemma for clinicians who prescribe carbapenems as empiric treatment for seriously ill patients.

This article explores the clinical impact of the relationship between carbapenem dosing and adverse event risks, pharmacodynamic-based dosing, and costs. It focuses on imipenem, meropenem, and doripenem, as they are more commonly used as empiric treatments for seriously ill patients in settings such as the ICU [9]. Ertapenem has not been discussed in this context because its lack of activity against $P$. aeruginosa and Acinetobacter spp. typically precludes its consideration for such cases [9]. Finally, it offers solutions to address this growing public health concern.

\section{Clinical roles of antipseudomonal carbapenems}

An analysis of data from the National Nosocomial Infections Surveillance system between 1986 and 2003 examined trends in the epidemiology of Gram-negative infections in ICUs [10]. While overall percentages of Gram-negative infections in ICU-treated pneumonias, surgical site infections,

$\mathrm{ESBL}=$ extended spectrum $\beta$-lactamase $; \mathrm{ICU}=$ intensive care unit; $\mathrm{MDR}=$ multidrug resistant $\mathrm{MIC}=$ minimum inhibitory concentration; $\mathrm{T}>\mathrm{MIC}=$ time greater than minimum inhibitory concentration. 
urinary tract infections, and bloodstream infections either remained similar or declined, significant increases were seen in infections caused by cephalosporin-resistant E. coli and Klebsiella pneumoniae (related to extended spectrum $\beta$-lactamase (ESBL)-producing strains), ceftazidime-resistant $P$. aeruginosa, imipenem-resistant $P$. aeruginosa, and isolates of Acinetobacter spp. resistant to amikacin, ceftazidime, or imipenem. The authors concluded that increase in the prevalence of multidrug resistance - usually defined as resistance to three or more of the antimicrobial agents antipseudomonal penicillins, antipseudomonal cephalosporins, fluoroquinolones, carbapenems, and the aminoglycosides [11,12] - may be the greatest concern for Gram-negative bacilli associated with hospital-acquired infections [10].

Antipseudomonal carbapenems - imipenem, meropenem and doripenem - have excellent activity against most strains of many bacterial species and are regarded as safe and generally well-tolerated. Because of their broad spectrum, the antipseudomonal carbapenems are often effective against organisms resistant to other antimicrobial agents and are frequently used as empiric therapy in the ICU for polymicrobial infections. Of note, these carbapenems are resistant to ESBLs, and so are of value in treating infections caused by ESBL-producing strains of Enterobacteriaceae. Antipseudomonal carbapenems are indicated for a variety of hospitaltreated infections, including intra-abdominal, urinary tract, and skin and skin structure infections. They are prescribed by hospitalists, surgeons, intensivists, wound care specialists, and infectious disease physicians in ICUs, postoperative surgical units, burn units, and long-term care facilities. This use may not always adhere to manufacturer-specific dosage and prescribing practices aimed at minimizing the development of carbapenem resistance in an effective manner.

In addition to empiric use of carbapenems, the use of this class for surgical prophylaxis has been proposed. While a recent study found a single prophylactic dose of ertapenem superior to cefotetan in colorectal surgery [13], the use of carbapenems for surgical prophylaxis remains controversial [13-16], and in the absence of more evidence favoring carbapenems for surgical prophylaxis, they are not recommended for use in this setting.

\section{Carbapenem dosing and seizure risk}

Multiple studies have found that imipenem and meropenem are associated with a dose-related increase in the risk for seizure events [3,4,17-25]. The mechanism is not fully understood $[3,26,27]$. Table 1 summarizes the range of seizure rates reported with either imipenem or meropenem.

In the largest report on seizures during imipenem treatment, underlying central nervous system disorders were common among patients who experienced seizures [17]. In this study, seizures occurred in $1.5 \%(37 / 2,516)$ of patients, although only $0.24 \%(6 / 2,516)$ were considered to be imipenem- related. A more recent study found no increase in seizure risk for patients treated with imipenem at a maximum dose of $2 \mathrm{mg} /$ day [3].

The risk of seizures with meropenem is widely believed to be lower than with imipenem [26], but the evidence is not definitive $[3,6]$. During clinical investigations, the overall seizure rate in meropenem-treated patients was $0.7 \%(20 / 2,904)$ [28], similar to the rate of $0.8 \%$ found in non-meningitis patients treated with meropenem [29]. Doripenem does not appear to have proconvulsive activity [30]. After more than a year in clinical use, there are no reports of doripenem-related seizures.

Although imipenem- or meropenem-related seizures are usually reversible on discontinuation and are manageable with anticonvulsants, the risk has made clinicians cautious about using these drugs at high doses, and this caution may be associated with the setting of upper limits on the dosing window for these carbapenems that are sub-therapeutic.

\section{Carbapenem dosing and pharmacodynamic considerations}

Imipenem, meropenem, and doripenem have elimination halflives of approximately 1 hour $[1,28,31]$. Like other $\beta$-lactams, carbapenems have time-dependent bactericidal activity that results from avid binding to penicillin-binding proteins and disruption of bacterial cell wall synthesis. Carbapenems are highly resistant to most $\beta$-lactamases, including ESBLs [32]. The key pharmacodynamic parameter is the time during which the carbapenem concentration exceeds the minimum inhibitory concentration ( $\mathrm{T}>\mathrm{MIC}$ ), which should be at least $20 \%$ of the dosing interval for bacteriostatic effect and $40 \%$ for maximum killing effect $[33,34]$.

Dosing of carbapenems in the clinical setting must be carefully judged to give the best chance of meeting or exceeding the pharmacodynamic bactericidal $\mathrm{T}>\mathrm{MIC}$ target of $40 \%$. Critical factors to take into account must include the severity of infection, patient-specific pharmacokinetic considerations and their impact on the drug concentration curve over time, and an assessment of the most likely causative pathogens. As carbapenems are often given empirically, judgments on this last point should be made based on local experience and on local antibiogram trends. When dealing with seriously ill patients, the possible presence of $P$. aeruginosa or Acinetobacter spp. should be considered, in addition to resistant strains of Enterobacteriaceae (for example, ESBL-producing strains). The potentially higher MIC values associated with these species or strains will be a factor in carbapenem selection and in the appropriate dosing of the chosen carbapenem to ensure achievement of the $\mathrm{T}>\mathrm{MIC}$ target for these difficult-to-treat organisms [35]. Ideally, to help prevent the risk of under- or overdosing, clinicians who can obtain carbapenem serum levels may consider doing so in ICU patients. 
Table 1

\begin{tabular}{|c|c|c|c|c|}
\hline Study & Patient population & Dosage & Seizure incidence & Notes \\
\hline \multicolumn{5}{|l|}{ Imipenem } \\
\hline $\begin{array}{l}\text { Winston et al. } \\
1984[24]\end{array}$ & $\begin{array}{l}35 \text { patients with infections } \\
\text { from imipenem-susceptible } \\
\text { organisms }\end{array}$ & $\begin{array}{l}4 \mathrm{~g} / \text { day (23 patients); } \\
<4 \text { g/day (12 patients) }\end{array}$ & None & \\
\hline $\begin{array}{l}\text { Calandra et al. } \\
1985[17]\end{array}$ & $\begin{array}{l}\text { First } 2,516 \text { patients treated; } \\
\text { most had significant } \\
\text { background disorders }\end{array}$ & $\begin{array}{l}<2 \text { g/day, } 32 \text { percent; } \\
2 \text { g/day, } 44 \text { percent; } \\
>2 \text { g/day, } 24 \text { percent }\end{array}$ & $\begin{array}{l}1.5 \text { percent }(37 / 2,516) \text { all } \\
\text { episodes; } 0.24 \text { percent } \\
(6 / 2,516) \text { imipenem related }\end{array}$ & $\begin{array}{l}\text { High rates of central } \\
\text { nervous system disorders } \\
\text { in patients with seizures }\end{array}$ \\
\hline $\begin{array}{l}\text { Winston et al. } \\
1988[25]\end{array}$ & $\begin{array}{l}29 \text { febrile granulocytopenic } \\
\text { patients }\end{array}$ & $1 \mathrm{~g} \mathrm{q} 6 \mathrm{~h}$ & 10.3 percent $(3 / 29)$ & $\begin{array}{l}\text { Versus } 0 \text { percent }(0 / 58) \\
\text { treated with } 2 \beta \text {-lactams }\end{array}$ \\
\hline $\begin{array}{l}\text { Eng et al. } \\
1989[4]\end{array}$ & First 22 patients treated & $\begin{array}{l}\text { Varied (500 } \mathrm{mg} \mathrm{q} 12 \mathrm{~h} \text { to } \\
1 \mathrm{~g} \mathrm{q} 6 \mathrm{~h})\end{array}$ & 22.7 percent $(5 / 22)$ & \\
\hline $\begin{array}{l}\text { Rolston et al. } \\
1992[22]\end{array}$ & $\begin{array}{l}371 \text { febrile neutropenic } \\
\text { cancer patients }\end{array}$ & $12.5 \mathrm{mg} / \mathrm{kg} \mathrm{q} 6 \mathrm{~h}$ & $\begin{array}{l}1.5 \text { percent }(3 / 196) \text { imipenem }+ \\
\text { vancomycin; } 3.4 \text { percent }(6 / 175) \\
\text { imipenem }+ \text { amikacin }\end{array}$ & $\begin{array}{l}1 \mathrm{~g} \mathrm{qh} 6 \text { for an } 80 \mathrm{~kg} \\
\text { patient }\end{array}$ \\
\hline $\begin{array}{l}\text { Norrby et al. } \\
1993 \text { [19] }\end{array}$ & $\begin{array}{l}197 \text { patients with severe } \\
\text { nosocomial infections }\end{array}$ & $\begin{array}{l}500 \mathrm{mg} q 6 \mathrm{~h} \text { adjusted for } \\
\text { renal dysfunction }\end{array}$ & 0.5 percent $(1 / 197)$ & $\begin{array}{l}\text { Versus } 0 \text { percent }(0 / 196) \\
\text { treated with ceftazidime }\end{array}$ \\
\hline $\begin{array}{l}\text { Raad et al. } \\
1996[21]\end{array}$ & $\begin{array}{l}198 \text { febrile neutropenic } \\
\text { cancer patients }\end{array}$ & $500 \mathrm{mg} \mathrm{q} 6 \mathrm{~h}$ & $\begin{array}{l}0.5 \text { percent }(1 / 198) \text { imipenem }+ \\
\text { vancomycin }\end{array}$ & $\begin{array}{l}\text { Versus } 0 \text { percent }(0 / 192) \\
\text { treated with aztreonam }+ \\
\text { vancomycin }\end{array}$ \\
\hline $\begin{array}{l}\text { Karadeniz et al. } \\
2000[18]\end{array}$ & $\begin{array}{l}82 \text { pediatric patients with } \\
\text { malignancies }\end{array}$ & $50 \mathrm{mg} / \mathrm{kg} /$ day in 3 doses & 3.6 percent $(3 / 82)$ & \\
\hline $\begin{array}{l}\text { Koppel et al. } \\
2001[3]\end{array}$ & 98 patients & Max. 2 g/day & $\begin{array}{l}4.0 / 1,000 \text { patient-days (on } \\
\text { imipenem); } 3.9 / 1,000 \text { patient- } \\
\text { days (not on imipenem) }\end{array}$ & $\begin{array}{l}\text { No increase in risk due to } \\
\text { imipenem }\end{array}$ \\
\hline $\begin{array}{l}\text { Winston et al. } \\
2001[94]\end{array}$ & $\begin{array}{l}541 \text { febrile granulocyto- } \\
\text { penic patients }\end{array}$ & $500 \mathrm{mg} \mathrm{q} 6 \mathrm{~h}$ & 2 percent & $\begin{array}{l}\text { O percent for clinafloxacin } \\
(200 \mathrm{mg} \text { every } 12 \mathrm{~h}) \\
P=0.06\end{array}$ \\
\hline \multicolumn{5}{|l|}{ Meropenem } \\
\hline $\begin{array}{l}\text { Sieger et al. } \\
1997[96]\end{array}$ & $\begin{array}{l}104 \text { patients with noso- } \\
\text { comial lower respiratory } \\
\text { tract infections }\end{array}$ & $1 \mathrm{~g} \mathrm{q} 8 \mathrm{~h}$ & $\begin{array}{l}2.9 \text { percent }(3 / 104) \text { all } \\
\text { episodes; } 0 \text { percent } \\
\text { meropenem related }\end{array}$ & \\
\hline $\begin{array}{l}\text { Norrby et al. } \\
1999 \text { [29] }\end{array}$ & $\begin{array}{l}4,872 \text { patients in multiple } \\
\text { trials }\end{array}$ & 0.5 to $1 \mathrm{~g} \mathrm{q} 8 \mathrm{~h}$ & $\begin{array}{l}\text { Meropenem related: } 0.08 \text { percent } \\
\text { (patients without meningitis); } \\
0 \text { percent (patients with meningitis) }\end{array}$ & \\
\hline
\end{tabular}

\section{Carbapenem dosing and efficacy}

Carbapenems such as imipenem and meropenem have a relatively narrow therapeutic window. The upper limit of this window is bounded by the dose-dependent risk of seizure adverse events, while the lower limit is set by pharmacodynamics. Carbapenems require a T>MIC of at least $40 \%$ of their dosing interval for maximal bactericidal activity, and attainment of this pharmacodynamic target depends on dosage, individual patient pharmacokinetics, and the MIC of the target pathogen.

Several studies suggest that low doses of some carbapenems are associated with decreased efficacy as reflected in failure of cure, relapse, and superinfections, especially when the infection involves species with high levels of resistance (for example, high percentage of pseudomonal isolates with $\mathrm{MICs}>4$ ), such as $P$. aeruginosa. In patients with soft tissue infections, a $2 \mathrm{~g} /$ day regimen of imipenem provided a response rate of $95 \%$ (56\% clinical cure, $38 \%$ improvement). Rates of microbiologic eradication ranged from $61 \%$ for $P$. aeruginosa to $100 \%$ for anaerobic bacteria [36]. In patients with febrile neutropenia, a study using the $2 \mathrm{~g} /$ day imipenem regimen reported a $77 \%$ response rate [37]. In patients with intra-abdominal infections, reported cure rates at the $2 \mathrm{~g} /$ day dosage range from $76 \%$ to $81 \%$ [38-40], and at a lower dosage $(1.5 \mathrm{~g} /$ day in three $500-\mathrm{mg}$ infusions 8 hours apart), the cure rate was $69 \%$ [41]. In the absence of controlled trials comparing different imipenem doses, these 
Probability of meropenem and imipenem attaining pharmacodynamic targets over entire dosing interval for 30,50 , and 100 percent T>MIC for selected bacterial populations [42]

\begin{tabular}{|c|c|c|c|c|c|c|}
\hline \multirow[b]{3}{*}{ Species } & \multicolumn{6}{|c|}{ Pharmacodynamic target for entire dosing interval } \\
\hline & \multicolumn{2}{|c|}{30 percent $\mathrm{T}>\mathrm{MIC}$} & \multicolumn{2}{|c|}{50 percent $\mathrm{T}>\mathrm{MIC}$} & \multicolumn{2}{|c|}{100 percent $\mathrm{T}>\mathrm{MIC}$} \\
\hline & Meropenem & Imipenem & Meropenem & Imipenem & Meropenem & Imipenem \\
\hline Escherichia coli & 100 & 100 & 100 & 100 & 100 & 94 \\
\hline Klebsiella pneumoniae & 100 & 100 & 99 & 100 & 99 & 91 \\
\hline Enterobacter cloacae & 100 & 100 & 100 & 100 & 95 & 71 \\
\hline Serratia marcescens & 99 & 99 & 99 & 99 & 97 & 57 \\
\hline Acinetobacter baumannii & 83 & 89 & 79 & 88 & 31 & 60 \\
\hline Pseudomonas aeruginosa & 93 & 92 & 87 & 87 & 47 & 27 \\
\hline
\end{tabular}

$\mathrm{T}>\mathrm{MIC}$, time greater than minimum inhibitory concentration.

data suggest that imipenem $2 \mathrm{~g} /$ day, which minimizes the incidence of seizure adverse events, may be less effective than $4 \mathrm{~g} /$ day. Thus, the need for a relatively low dose of imipenem to avoid seizure adverse events may offset its potential antimicrobial activity [4].

Kuti and colleagues [42] performed a Monte Carlo analysis to evaluate the probability of a $500 \mathrm{mg} / 6$ hour dosing regimen of meropenem and imipenem to attain three different pharmacodynamic targets over the entire dosing interval ( $\mathrm{T}>\mathrm{MIC}$ $30 \%, \mathrm{~T}>\mathrm{MIC} 50 \%$, and T>MIC 100\%) for different pathogens. Probabilities of staying above the MIC target throughout the dosing interval were similar between the two agents for $\mathrm{T}>\mathrm{MIC} 30 \%$ or $\mathrm{T}>\mathrm{MIC} 50 \%$ (Table 2 ). Figure 1 shows the probability of attaining the dosing targets across a range of MIC values, and while the differences are statistically significant, this calculation does not take into account protein binding differences that affect drug availability, reducing the accuracy of the findings, so the clinical significance is not clear [42]. Nevertheless, the model demonstrates the importance and complexities involved in delivering drugs effectively, taking into account pharmacodynamic properties.

\section{Carbapenem resistance}

Levels of resistance have increased considerably since the introduction of the first carbapenem, particularly among Gram-negative organisms [43]. Carbapenem resistance among $A$. baumannii and $P$. aeruginosa is a pressing problem $[2,24,44-55]$ with steady increases in the prevalence and geographic spread of carbapenem-resistant strains [56-58], and reported rates of resistance as high as $16.3 \%$ worldwide. In North America, rates of 3.1\% for P. aeruginosa [59] and 3.2\% for Acinetobacter spp. [60] have been reported. Between 1997 and 1999 and 2004 and 2006, imipenem nonsusceptibility in $P$. aeruginosa increased from $23.6 \%$ to 29.3\% and from 33.3\% to $47.5 \%$ in Acinetobacter spp. [43]. Resistance in K. pneumoniae has also been reported [61].
Figure 1

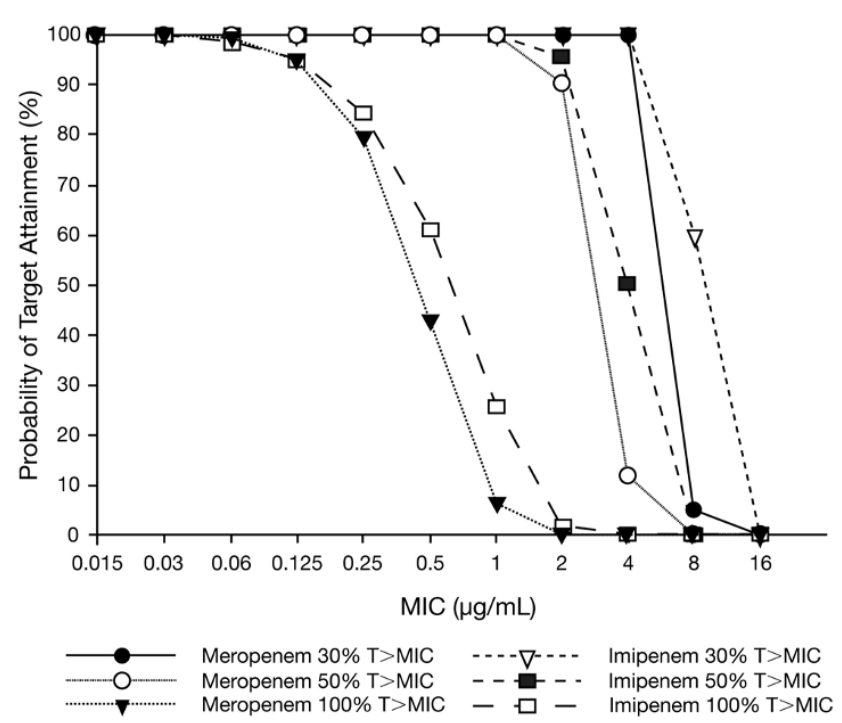

Probability of attaining pharmacodynamic target during entire dosing interval ( $\mathrm{T}>\mathrm{MIC}>30 \%, 50 \%$, and $100 \%$ ) as a function of MIC for imipenem and meropenem at a dosage of $500 \mathrm{mg} \mathrm{q} 6 \mathrm{~h}$. The $30 \%$ and $50 \%$ targets represent conservative estimates for bacteriostatic and bactericidal activity, respectively. Each curve shows the likelihood of the drug to stay above the target MIC for the entire dosing period based on the pathogen's MIC. Note the steep declines in probabilities for MIC values between 0.5 and 4 . Reproduced with permission from Kuti et al. [42].

For 2004 and 2005, meropenem nonsusceptibility for $P$. aeruginosa was $9.7 \%$ and $12.4 \%$, respectively, and for Acinetobacter spp. was $23.9 \%$ and $14.4 \%$, respectively [62].

Three mechanisms for carbapenem resistance development have been identified: reduced carbapenem influx due to changes in expression of outer membrane porins [63], 
secretion of carbapenemases [44,61,63,64], and efflux pump production [65]. Studies have suggested that resistance to imipenem may occur through a loss of porin expression alone, whereas with meropenem and doripenem the combination of porin loss together with increased efflux pump production is required to confer resistance [66-68].

Carbapenemases affect all three antipseudomonal carbapenems. At present they are relatively rare in the US; however, carbapenemases are a source for future concern as they inactivate not just carbapenems but virtually all $\beta$-lactam based antibacterials. Furthermore, detection of carbapenemases is not well-addressed by current automated testing systems. One study found that clinical laboratory testing misidentified approximately 15\% of carbapenemase-producing K. pneumoniae strains as imipenem-susceptible [69]. A second study evaluated several automated test systems for detection of carbapenem resistance in 15 strains previously identified by broth microdilution as non-susceptible to imipenem and meropenem [70]. Depending on the test system used, between 1 and 13 of the 15 nonsusceptible strains were misidentified as susceptible. Although several methods for assessing carbapenemase production have been proposed [71-74], current guidelines do not include protocols for assaying carbapenemase production.

Imipenem and other carbapenems are considered the most effective available agents for treating Acinetobacter infections $[75,76]$. However, $A$. baumannii strains with high-level carbapenem resistance have become widespread [44]. Carbapenemresistant $A$. baumannii has been reported worldwide, with outbreaks in the United States [51], Europe [45,49,54], South America [47], and Asia [50,53]. A recent Turkish study of patients with postneurosurgical meningitis found that $45 \%$ of 29 infections due to Acinetobacter spp. were imipenemresistant before the initiation of therapy [52].

\section{Carbapenem dosing and resistance}

Resistance to carbapenems probably reflects two major drivers: the 20-year history of widespread use of imipenem and other carbapenems, and dosing that is suboptimal for pathogens with higher MICs, including intermediate and resistant organisms.

The general association between antibiotic use and antibiotic resistance is well known and believed to be causal [77]. Several reports exemplify this linkage for carbapenems. A study in a 600-bed community hospital found a strong association between imipenem usage and resistance in $P$. aeruginosa (Figure 2), although it is unclear whether the strain was treated adequately or if infection control techniques were uniformly adopted [78]. In another study, an attempt to prevent cephalosporin resistance by decreasing cephalosporin use caused a compensatory $140.6 \%$ increase in carbapenem use and an increase of $68.7 \%$ in the prevalence of imipenem-resistant $P$. aeruginosa infections [79].
Figure 2

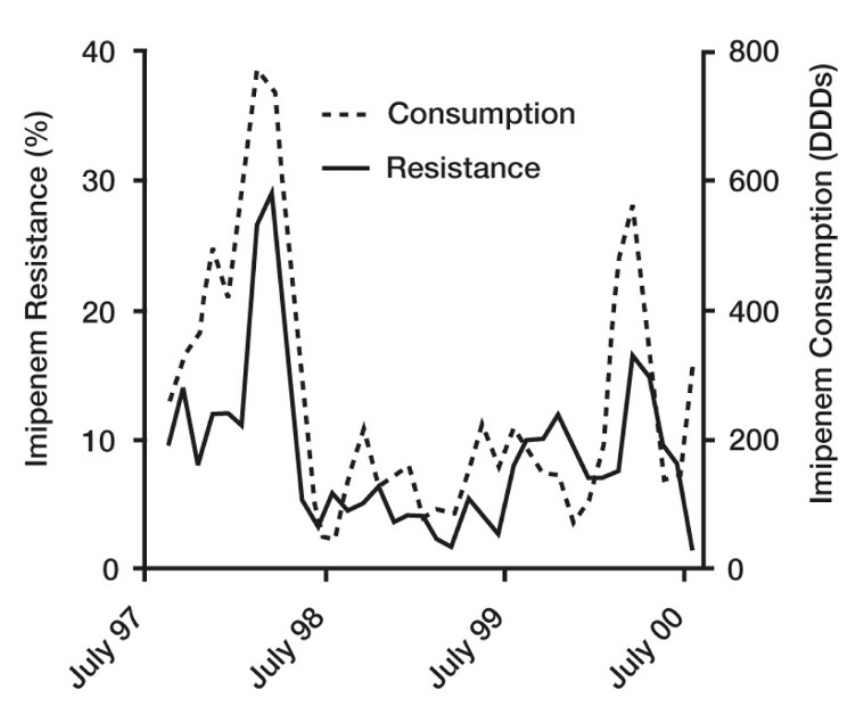

Correlation between imipenem usage and imipenem resistance in $P$. aeruginosa in a community hospital. DDD, defined daily dose. Reproduced with permission from [78].

Similarly, a Polish pediatric hospital in which carbapenem use quadrupled between 1993 and 2002 found that the percentage of isolates susceptible to imipenem decreased from $95.7 \%$ to $81.7 \%$, and that $\mathrm{MIC}_{90}$ increased from $2 \mathrm{mg} / \mathrm{dL}$ to $16 \mathrm{mg} / \mathrm{dL}$ over the same period (Figure 3) [80].

Suboptimal dosing is a well known driver for the development of antibiotic resistance during antibiotic therapy [8]. As already noted, optimal bactericidal dosing for carbapenems requires maintaining drug levels so that $\mathrm{T}>\mathrm{MIC}$ exceeds $40 \%$ of the dosing interval $[26,81,82]$. The standard $500 \mathrm{mg}$ $\mathrm{q} 6 \mathrm{~h}$ regimen for imipenem/cilastatin meets this criterion in healthy individuals for susceptible pathogens. However, as shown in Figure 4, the $500 \mathrm{mg}$ q6h regimen provides T $>$ MIC values of $38 \%$ and $23 \%$, respectively, for organisms with 1.5 to $3.0 \mathrm{mg} / \mathrm{dL}$ and 3 to $6 \mathrm{mg} / \mathrm{dL}$ MIC values [83]. Thus, the $500 \mathrm{mg}$ q6h regimen and lower dosages may not be adequate for pathogens with a MIC $>1.5 \mathrm{mg} / \mathrm{dL}$.

Also of concern is the emergence of resistance during a course of carbapenem therapy. Fink and colleagues [48] investigated imipenem $3 \mathrm{~g} /$ day $(1,000 \mathrm{mg}$ q $8 \mathrm{~h})$ in 200 patients with severe pneumonia. Microbiologic eradication occurred in $59 \%$ of the imipenem-treated patients. A total of 44 different strains of $P$. aeruginosa were isolated from 32 of these patients, and $50 \%$ of these strains developed imipenem resistance during the trial. More recently, in a study of nosocomial pneumonia, resistance developed in 33\% (nine of 27) of patients with $P$. aeruginosa infections during treatment with imipenem $500 \mathrm{mg} \mathrm{q6h}$. Resistance was present at the start of therapy in 5 of $32(16 \%)$ patients (5 patients in this group were excluded after randomization) [55]. Use of 
Figure 3
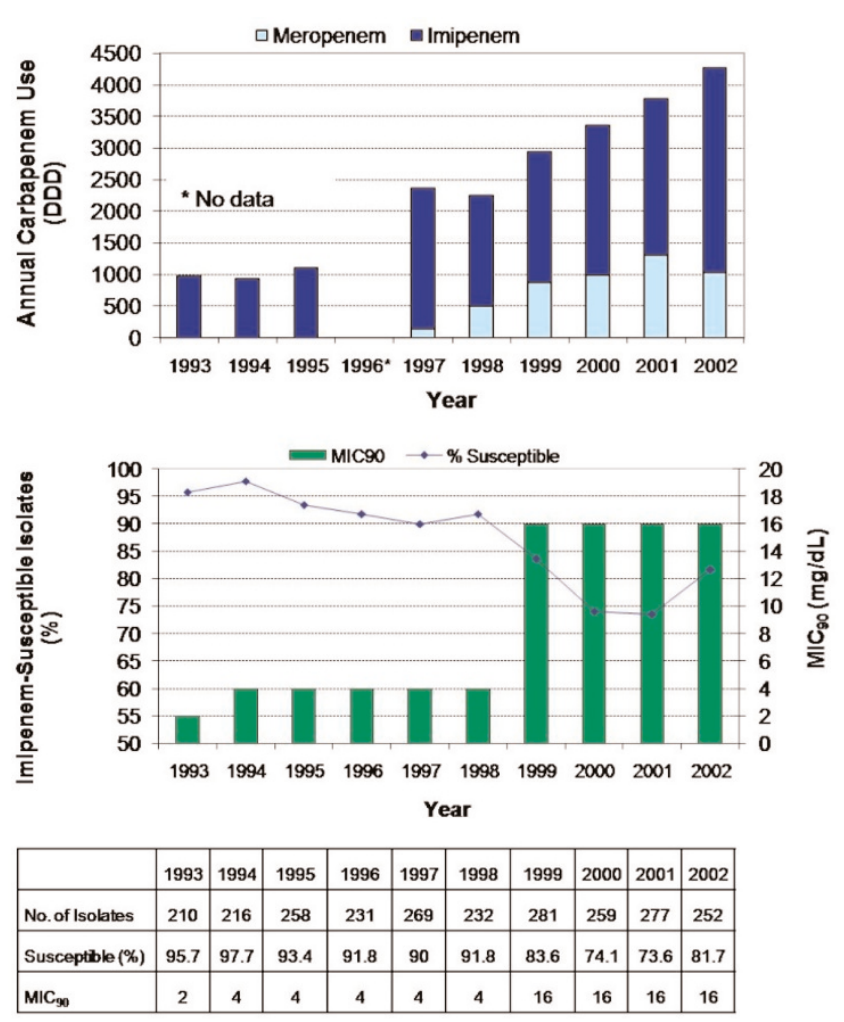

Imipenem susceptibility and carbapenem use at a Polish pediatric hospital (1993 to 2002). DDD, defined daily dose. Reprinted from Patzer and Dzierzanowska [80], with permission from Elsevier.

imipenem as monotherapy to treat $P$. aeruginosa is not recommended because, as the examples above show, imipenem monotherapy is associated with considerable risk for $P$. aeruginosa resistance $[84,85]$.

Intermediate susceptibility to imipenem is common among $P$. aeruginosa strains, and imipenem $500 \mathrm{mg} \mathrm{q} 6 \mathrm{~h}$ is frequently unable to achieve a sufficient $\mathrm{T}>\mathrm{MIC}$ for effective eradication. In a trial comparing imipenem/cilastatin with ceftazidime for serious nosocomial infections, $P$. aeruginosa infections resolved in only 8 of 19 patients treated with imipenem, compared with 14 of 17 infections in patients treated with ceftazidime $(P=0.004)$; resistance developed in 6 of 19 and 1 of 17 patients, respectively [19].

Altered carbapenem $\mathrm{T}>\mathrm{MIC}$ values in an individual patient may also reflect the presence of severe illness, which can affect any pharmacokinetic parameter of a drug $[81,86]$. Regimens that do not account for these conditions may not maintain antibiotic levels sufficient for eradication [86]. One example is patients who are anuric or receiving continuous renal replacement therapy. Current continuous renal replacement therapy techniques provide rapid systemic drug clearance, and carbapenem regimens that are not adjusted
Figure 4

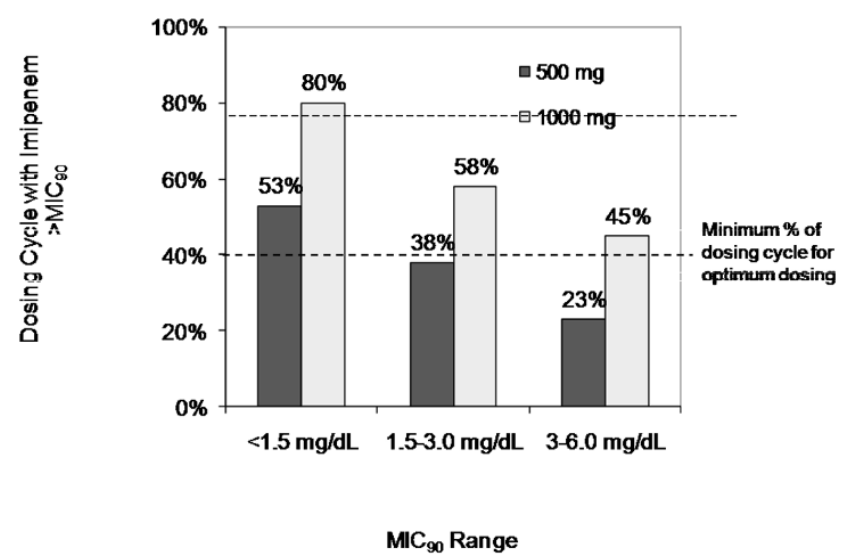

Effect of imipenem dose on the time during which serum imipenem exceeds the $\mathrm{MIC}_{90}$ in healthy volunteers after a 30 minute infusion [83]. The dashed line shows the percentage of the dosing cycle required for optimal dosing.

accordingly may result in suboptimal drug levels, ineffective eradication, and an increased likelihood of resistance [81].

Overall, these considerations suggest that standard carbapenem dosages (for example, imipenem $2 \mathrm{~g} /$ day) may be suboptimal in terms of microbiologic eradication and resistance development for some infections in some patients, particularly pathogens with intermediate susceptibility and patients with altered pharmacokinetic properties when doses are not adjusted appropriately.

\section{Clinical implications}

The increasing prevalence of carbapenem resistance has broad and significant clinical implications because mortality and the cost of care are significantly increased in patients with carbapenem-resistant infections. Mortality in patients with carbapenem-resistant infections is approximately twice that of patients with carbapenem-susceptible infections: Kwon and colleagues [87] reported mortality rates of $57 \%$ and $27.5 \%$, respectively, in patients with imipenem-resistant and imipenemsusceptible Acinetobacter bacteremia (relative risk 30-day mortality was 2.019 (95\% confidence interval, 1.18 to 3.69 ; $P=0.007)$. The primary risk factor for mortality was the use of discordant antimicrobial therapy, that is, when the pathogen was not susceptible to any agent in the antimicrobial regimen [87]. Studies of multidrug-resistant (MDR) $P$. aeruginosa infections report an odds ratio for mortality of 15.13 (95\% confidence interval, 1.90 to $323.13 ; P=0.001$ ) for MDR versus susceptible infections in patients with $P$. aeruginosa bacteremia [88], and hospital costs for MDR and susceptible infections of $\$ 54,081$ and $\$ 22,116$, respectively [89].

In addition, resistance can be transmitted and consequently lead to outbreaks of carbapenem-resistant infections. 
Mikolajczyk and colleagues [90] estimated that 45\% of imipenem-resistant $P$. aeruginosa infections result from transmission. Multiple outbreaks of carbapenem-resistant $A$. baumannii and $P$. aeruginosa have been reported, including a major citywide outbreak that occurred in 15 Brooklyn, NY hospitals in 1999. During the outbreak, carbapenem resistance was found in $53 \%$ of $A$. baumannii isolates and $24 \%$ of $P$. aeruginosa isolates. Approximately 400 patients were infected or colonized with a carbapenem-resistant strain [91]. Multidrug-resistant $A$. baumannii and $P$. aeruginosa are now endemic in the New York area, and the production of carbapenemases is increasingly common in $K$. pneumoniae and E. coli $[56,58,69]$.

The increasing prevalence of imipenem resistance may also affect dosing requirements. In the past, before the emergence of MDR organisms became a common problem, the clinical impact of regimens using low imipenem dosages was relatively minor. With the emergence of MDR $P$. aeruginosa and Acinetobacter spp., inadequate dosing is increasingly likely to affect outcomes.

Although it is possible to prevent and control these outbreaks using a variety of measures such as patient screening and isolation, resistance monitoring, and infection control procedures, it is prudent to take measures to prevent or slow the development of carbapenem resistance.

Possible approaches to managing the problem include the use of novel dosing regimens, including extended infusions [92-94] and the use of novel or alternative antibiotic agents. Regimens using longer infusion times may help ensure that drug levels are maintained above the $\mathrm{MIC}_{90}$ for at least $40 \%$ of the dosing interval. Alternative antibiotic agents could include novel agents, carbapenems or other agents, and combination therapies. Alternative agents can be evaluated by the criteria put forth by the Council for Appropriate and Rational Antibiotic Therapy (CARAT). These criteria include the strength of evidence supporting the use of the antibiotic, the expected therapeutic benefits and the possibility of resistance, the adverse-event profile, the cost-effectiveness of therapy with the agent, and the appropriate dosage and duration [95]. Cost-containment strategies may have to be adjusted to maintain adequate carbapenem dosing. Greater awareness and education regarding MDR pathogens and carbapenem treatment issues across hospital departments remains a vital need.

\section{Conclusion}

Imipenem and meropenem have been a useful part of the antimicrobial armamentarium for 20 and 10 years, respectively, and continue as valuable agents for treatment of Gramnegative infections. However, they have a narrow therapeutic window and the need for low-dose therapy to avoid neurotoxicity and the need for high-dose therapy to ensure efficacy and prevent the development of resistance are in constant conflict. It is not yet clear whether an optimal antimicrobial dosage is attainable, given the seizure risk, or a suboptimal dosage acceptable, given the risks for treatment failure and resistance development. While avoidance of seizure adverse events may limit dosages - for example, imipenem $2 \mathrm{~g} /$ day or less (adjusted as necessary for renal dysfunction and other conditions) - these dosages are likely to be suboptimal for treatment of infections involving $P$. aeruginosa, $A$. baumannii, and other organisms with intermediate susceptibility. Underdosing may well decrease the efficacy of therapy while increasing the probability of resistance development.

Solutions include increasing awareness of treating resistant organisms, utilizing optimal dosing regimens in areas of the hospital where multiresistant organisms are more likely encountered, using alternative antimicrobials with more favorable pharmacokinetics, pharmacodynamics, and adverse-event profiles, and using newer carbapenems with lower propensity for resistance development (for example, reduced expression of efflux pumps or greater stability against carbapenemases). Achieving success requires hospital systems and physicians to continue to work together to create clinical solutions that optimize patient care.

\section{Competing interests}

TGS has been a consultant for Ortho-McNeil ${ }^{\circledR}$, Division of Ortho-McNeil-Janssen Pharmaceuticals, Inc. and is a member of the Speakers' Bureau for Pfizer, Inc. and Ortho-McNeil ${ }^{\mathbb{Q}}$. TGS has not received research funding.

\section{Acknowledgments}

The author would like to acknowledge Ben Caref, PhD (The Falk Group, LLC, New York, NY), who provided medical writing and editorial assistance. Ortho-McNeil ${ }^{\circledR}$ provided financial support for this assistance.

\section{References}

1. Primaxin IV (imipenem and cilastatin for injection) [Package Insert]. Whitehouse Station, NJ: Merck \& Co., Inc.; 2006.

2. Calandra GB, Ricci FM, Wang C, Brown KR: The efficacy results and safety profile of imipenem/cilastatin from the clinical research trials. J Clin Pharmacol 1988, 28:120-127.

3. Koppel BS, Hauser WA, Politis C, van DD, Daras M: Seizures in the critically ill: the role of imipenem. Epilepsia 2001, 42:15901593.

4. Eng RH, Munsif AN, Yangco BG, Smith SM, Chmel H: Seizure propensity with imipenem. Arch Intern Med 1989, 149:18811883.

5. Coves-Orts FJ, Borras-Blasco J, Navarro-Ruiz A, Murcia-Lopez A, Palacios-Ortega F: Acute seizures due to a probable interaction between valproic acid and meropenem. Ann Pharmacother 2005, 39:533-537.

6. Schranz J: Comparisons of seizure incidence and adverse experiences between imipenem and meropenem. Crit Care Med 1998, 26:1464-1466.

7. Spriet I, Meersseman W, De TE, Wilmer A, Casteels M, Willems L. Meropenem-valproic acid interaction in patients with cefepime-associated status epilepticus. Am J Health Syst Pharm 2007, 64:54-58.

8. Peterson LR: Squeezing the antibiotic balloon: the impact of antimicrobial classes on emerging resistance. Clin Microbiol Infect 2005, 11(Suppl 5):4-16.

9. Zhanel GG, Wiebe R, Dilay L, Thomson K, Rubinstein E, Hoban 
DJ, Noreddin AM, Karlowsky JA: Comparative review of the carbapenems. Drugs 2007, 67:1027-1052.

10. Gaynes R, Edwards JR, National Nosocomial Infections Surveillance System: Overview of nosocomial infections caused by Gram-negative bacilli. Clin Infect Dis 2005, 41:848-854.

11. Defez C, Fabbro-Peray P, Bouziges N, Gouby A, Mahamat A, Daurès JP, Sotto A: Risk factors for multidrug-resistant Pseudomonas aeruginosa nosocomial infection. J Hosp Infect 2004, 57:209-216.

12. Giske CG, Monnet DL, Cars O, Carmeli Y: Clinical and economic impact of common multidrug-resistant Gram-negative bacilli. Antimicrob Agents Chemother 2008, 52:813-821.

13. Itani KM, Wilson SE, Awad SS, Jensen EH, Finn TS, Abramson MA: Ertapenem versus cefotetan prophylaxis in elective colorectal surgery. N Engl J Med 2006, 355:2640-2651.

14. Moine $\mathrm{P}$, Asehnoune $\mathrm{K}$ : Antibiotic prophylaxis in colorectal surgery. N Engl J Med 2007, 356:1684.

15. Sexton DJ: Carbapenems for surgical prophylaxis? $N$ Engl J Med 2006, 355:2693-2695.

16. Spievack AR: Antibiotic prophylaxis in colorectal surgery. $N$ Engl J Med 2007, 356:1685.

17. Calandra GB, Brown KR, Grad LC, Ahonkhai VI, Wang C, Aziz MA: Review of adverse experiences and tolerability in the first 2,516 patients treated with imipenem/cilastatin. $\mathrm{Am} J \mathrm{Med}$ 1985, 78:73-78.

18. Karadeniz C, Oguz A, Canter B, Serdaroglu A: Incidence of seizures in pediatric cancer patients treated with imipenem/ cilastatin. Pediatr Hematol Oncol 2000, 17:585-590.

19. Norrby SR, Finch RG, Glauser M: Monotherapy in serious hospital-acquired infections: a clinical trial of ceftazidime versus imipenem/cilastatin. European Study Group. J Antimicrob Chemother 1993, 31:927-937.

20. Norrby SR, Newell PA, Faulkner KL, Lesky W: Safety profile of meropenem: international clinical experience based on the first 3125 patients treated with meropenem. J Antimicrob Chemother 1995, 36(Suppl A):207-223.

21. Raad II, Whimbey EE, Rolston KV, Abi-Said D, Hachem RY, Pandya RG, Ghaddar HM, Karl CL, Bodey GP: A comparison of aztreonam plus vancomycin and imipenem plus vancomycin as initial therapy for febrile neutropenic cancer patients. Cancer 1996, 77:1386-1394.

22. Rolston KV, Berkey P, Bodey GP, Anaissie EJ, Khardori NM, Joshi $\mathrm{JH}$, Keating MJ, Holmes FA, Cabanillas FF, Elting L: A comparison of imipenem to ceftazidime with or without amikacin as empiric therapy in febrile neutropenic patients. Arch Intern Med 1992, 152:283-291.

23. Sieger B, Berman SJ, Geckler RW, Farkas SA: Empiric treatment of hospital-acquired lower respiratory tract infections with meropenem or ceftazidime with tobramycin: a randomized study. Meropenem Lower Respiratory Infection Group. Crit Care Med 1997, 25:1663-1670.

24. Winston DJ, McGrattan MA, Busuttil RW: Imipenem therapy of Pseudomonas aeruginosa and other serious bacterial infections. Antimicrob Agents Chemother 1984, 26:673-677.

25. Winston DJ, Ho WG, Bruckner DA, Gale RP, Champlin RE: Controlled trials of double beta-lactam therapy with cefoperazone plus piperacillin in febrile granulocytopenic patients. $A m ~ J$ Med 1988, 85:21-30.

26. Mouton JW, Touzw DJ, Horrevorts AM, Vinks AA. Comparative pharmacokinetics of the carbapenems: clinical implications. Clin Pharmacokinet 2000, 39:185-201.

27. Norrby SR: Neurotoxicity of carbapenem antibacterials. Drug Saf 1996, 15:87-90

28. Merrem IV (meropenem for injection) [Package Insert].Wilmington, DE: AstraZeneca Pharmaceuticals LP; 2007.

29. Norrby SR, Gildon KM: Safety profile of meropenem: a review of nearly 5,000 patients treated with meropenem. Scand J Infect Dis 1999, 31:3-10.

30. Horiuchi M, Kimura M, Tokumura M, Hasebe N, Arai T, Abe K: Absence of convulsive liability of doripenem, a new carbapenem antibiotic, in comparison with beta-lactam antibiotics. Toxicology 2006, 222:114-124.

31. Doribax (doripenem for injection) [Package Insert]. Raritan, NJ: Ortho-McNeil Pharmaceutical, Inc.; 2007.

32. Petri WA: Antimicrobial agents: penicillins, cephalosporins, and other $\beta$-lactam antibiotics. In Goodman \& Gilman's The Pharmacological Basis of Therapeutics. 10th edition. Edited by
Goodman LS, Hardman JG, Limbird LE, Gilman AG. New York: McGraw-Hill; 2001:1189-1218.

33. Craig WA: Pharmacokinetic/pharmacodynamic parameters: rationale for antibacterial dosing of mice and men. Clin Infect Dis 1998, 26:1-10.

34. Drusano GL: Antimicrobial pharmacodynamics: critical interactions of 'bug and drug'. Nat Rev Microbiol 2004, 2:289-300.

35. Cheatham SC, Kays MB, Smith DW, Wack MF, Sowinski KM: Steady-state pharmacokinetics and pharmacodynamics of meropenem in hospitalized patients. Pharmacotherapy 2008, 28:691-698.

36. Marier RL: Role of imipenem/cilastatin in the treatment of soft tissue infections. Am J Med 1985, 78:140-144.

37. Liang R, Yung R, Chiu E, Chau PY, Chan TK, Lam WK, Todd D: Ceftazidime versus imipenem-cilastatin as initial monotherapy for febrile neutropenic patients. Antimicrob Agents Chemother 1990, 34:1336-1341.

38. Barie PS, Vogel SB, Dellinger EP, Rotstein OD, Solomkin JS, Yang JY, Baumgartner TF: A randomized, double-blind clinical trial comparing cefepime plus metronidazole with imipenemcilastatin in the treatment of complicated intra-abdominal infections. Cefepime Intra-abdominal Infection Study Group. Arch Surg 1997, 132:1294-1302.

39. Solomkin JS, Dellinger EP, Christou NV, Busuttil RW: Results of a multicenter trial comparing imipenem/cilastatin to tobramycin/clindamycin for intra-abdominal infections. Ann Surg 1990, 212:581-591.

40. Solomkin JS, Reinhart HH, Dellinger EP, Bohnen JM, Rotstein OD, Vogel SB, Simms HH, Hill CS, Bjornson HS, Haverstock DC, Coul;ter HO, Echols RM: Results of a randomized trial comparing sequential intravenous/oral treatment with ciprofloxacin plus metronidazole to imipenem/cilastatin for intra-abdominal infections. The Intra-Abdominal Infection Study Group. Ann Surg 1996, 223:303-315.

41. Brismar B, Malmborg AS, Tunevall G, Wretland B, Bergmann L, Mentzing LO, Nyström PO, Kihlström E, Backstrand B, Skau T, Kasholm-Tengue B, Sjöberg L, Ollson-Liljequist B, Tally FP, Gatenbeck L, Eklund AE, Nord CE: Piperacillin-tazobactam versus imipenem-cilastatin for treatment of intra-abdominal infections. Antimicrob Agents Chemother 1992, 36:2766-2773.

42. Kuti JL, Florea NR, Nightingale CH, Nicolau DP: Pharmacodynamics of meropenem and imipenem against Enterobacteriaceae, Acinetobacter baumannii, and Pseudomonas aeruginosa. Pharmacotherapy 2004, 24:8-15.

43. Fritsche TR, Sader HS, Strabala P, Jones RN: Antibiotic susceptibility of respiratory bacterial isolates. 2007:P 375.

44. Brown S, Amyes S: OXA (beta)-lactamases in Acinetobacter: the story so far. J Antimicrob Chemother 2006, 57:1-3.

45. Bogaerts $P$, Naas T, Wybo I, Bauraing C, Soetens O, Piérard D, Nordmann $P$, Glupczynski $Y$ : Outbreak of infection by carbapenem-resistant Acinetobacter baumannii producing the carbapenemase OXA-58 in Belgium. J Clin Microbio/ 2006, 44: 4189-4192.

46. Cometta A, Baumgartner JD, Lew D, Zimmlerli W, Pittet D, Chopart P, Schaad U, Herter C, Eggimann P, Huber O, Ricou B, Suter P, Auckenthaler R, Chiolero R, Bille J, Scheidegger C, Frei $\mathrm{R}$, Glauser MP: Prospective randomized comparison of imipenem monotherapy with imipenem plus netilmicin for treatment of severe infections in nonneutropenic patients. Antimicrob Agents Chemother 1994, 38:1309-1313.

47. Dalla-Costa LM, Coelho JM, Souza HA, Castro ME, Stier CJ, Bragagnolo KL, Rea-Neto A, Penteado-Filho SR, Livermore DM, Woodford N: Outbreak of carbapenem-resistant Acinetobacter baumannii producing the OXA-23 enzyme in Curitiba, Brazil. $J$ Clin Microbio/ 2003, 41:3403-3406.

48. Fink MP, Snydman DR, Niederman MS, Leeper KV, Johnson RH, Heard SO, Wunderink RG, Caldwell JW, Schentag JJ, Siami GA, Zameck Rl, Haverstock DC, Reinhart HH, Echols RM: Treatment of severe pneumonia in hospitalized patients: results of a multicenter, randomized, double-blind trial comparing intravenous ciprofloxacin with imipenem-cilastatin. The Severe Pneumonia Study Group. Antimicrob Agents Chemother 1994, 38:547-557.

49. Heritier C, Dubouix A, Poirel L, Marty N, Nordmann P: A nosocomial outbreak of Acinetobacter baumannii isolates expressing the carbapenem-hydrolysing oxacillinase OXA-58. J Antimicrob Chemother 2005, 55:115-118. 
50. Jeong SH, Bae IK, Park KO, An YJ, Sohn SG, Jang SJ, Sung KH, Yang KS, Lee K, Young D, Lee SH: Outbreaks of imipenemresistant Acinetobacter baumannii producing carbapenemases in Korea. J Microbio/ 2006, 44:423-431.

51. Lolans K, Rice TW, Munoz-Price LS, Quinn JP: Multicity outbreak of carbapenem-resistant Acinetobacter baumannii isolates producing the carbapenemase OXA-40. Antimicrob Agents Chemother 2006, 50:2941-2945.

52. Metan G, Alp E, Aygen B, Sumerkan B: Carbapenem-resistant Acinetobacter baumannii: an emerging threat for patients with post-neurosurgical meningitis. Int J Antimicrob Agents 2007, 29:112-113.

53. Naas T, Levy M, Hirschauer C, Marchandin H, Nordmann P. Outbreak of carbapenem-resistant Acinetobacter baumannii producing the carbapenemase OXA-23 in a tertiary care hospital of Papeete, French Polynesia. J Clin Microbiol 2005, 43:48264829.

54. Pournaras S, Markogiannakis A, Ikonomidis A, Kondyli L, Bethimouti K, Maniatis AN, Legakis NJ, Tsakris A: Outbreak of multiple clones of imipenem-resistant Acinetobacter baumannii isolates expressing OXA-58 carbapenemase in an intensive care unit. J Antimicrob Chemother 2006, 57:557-561.

55. Zanetti G, Bally F, Greub G, Garbino J, Kinge T, Lew D, Romand JA, Bille J, Aymon D, Stratchounski L, Krawczyk L, Rubinstein E, Schaller MD, Chiolero R, Glauser MP, Cometta A: Cefepime versus imipenem-cilastatin for treatment of nosocomial pneumonia in intensive care unit patients: a multicenter, evaluatorblind, prospective, randomized study. Cefepime Study Group. Antimicrob Agents Chemother 2003, 47:3442-3447.

56. Landman D, Bratu S, Kochar S, Panwar M, Trehan M, Doymaz M, Quale J: Evolution of antimicrobial resistance among Pseudomonas aeruginosa, Acinetobacter baumannii and Klebsiella pneumoniae in Brooklyn, NY. J Antimicrob Chemother 2007, 60:78-82.

57. Bratu S, Brooks S, Burney S, Kochar S, Gupta J, Landman D, Quale J: Detection and spread of Escherichia coli possessing the plasmid-borne carbapenemase KPC-2 in Brooklyn, New York. Clin Infect Dis 2007, 44:972-975.

58. Bratu S, Landman D, Haag R, Recco R, Eramo A, Alam M, Quale $\mathrm{J}$ : Rapid spread of carbapenem-resistant Klebsiella pneumoniae in New York City: a new threat to our antibiotic armamentarium. Arch Intern Med 2005, 165:1430-1435.

59. Turner PJ: Meropenem and imipenem activity against Pseudomonas aeruginosa isolates from the MYSTIC Program. Diagn Microbiol Infect Dis 2006, 56:341-344.

60. Rhomberg PR, Jones RN: Contemporary activity of meropenem and comparator broad-spectrum agents: MYSTIC program report from the United States component (2005). Diagn Microbiol Infect Dis 2007, 57:207-215.

61. Kim SY, Park YJ, Yu JK, Kim HS, Park YS, Yoon JB, Yoo JY, Lee $\mathrm{K}$ : Prevalence and mechanisms of decreased susceptibility to carbapenems in Klebsiella pneumoniae isolates. Diagn Microbiol Infect Dis 2007, 57:85-91.

62. Rhomberg PR, Jones RN: Contemporary activity of meropenem and comparator broad-spectrum agents: MYSTIC program report from the United States component (2005). Diagn Microbiol Infect Dis 2007, 57:207-215.

63. Clark RB: Imipenem resistance among Acinetobacter baumannii: association with reduced expression of a 33-36 kDa outer membrane protein. J Antimicrob Chemother 1996, 38: 245-251.

64. Quinn JP, Studemeister AE, DiVincenzo CA, Lerner SA: Resistance to imipenem in Pseudomonas aeruginosa: clinical experience and biochemical mechanisms. Rev Infect Dis 1988, 10: 892-898.

65. Bornet $C$, Chollet R, Malléa M, Chevalier J, Davin-Regli A, Pagès $\mathrm{JM}$, Bollet C: Imipenem and expression of multidrug efflux pump in Enterobacter aerogenes. Biochem Biophys Res Commun 2003, 301:985-990.

66. Livermore DM, Oakton KJ, Carter MW, Warner M: Activity of ertapenem (MK-0826) versus Enterobacteriaceae with potent beta-lactamases. Antimicrob Agents Chemother 2001, 45: 2831-2837.

67. Mushtaq S, Ge Y, Livermore DM: Doripenem versus Pseudomonas aeruginosa in vitro: activity against characterized isolates, mutants, and transconjugants and resistance selection potential. Antimicrob Agents Chemother 2004; 48:
3086-3092.

68. Sakyo S, Tomita H, Tanimoto K, Fujimoto S, lke Y. Potency of carbapenems for the prevention of carbapenem-resistant mutants of Pseudomonas aeruginosa: the high potency of a new carbapenem doripenem. J Antibiot (Tokyo) 2006, 59:220228.

69. Bratu S, Mooty M, Nichani S, Landman D, Gullans C, Pettinato B, Karumudi U, Tolaney P, Quale J: Emergence of KPC-possessing Klebsiella pneumoniae in Brooklyn, New York: epidemiology and recommendations for detection. Antimicrob Agents Chemother 2005, 49:3018-3020.

70. Tenover FC, Kalsi RK, Williams PP, Stocker S, Lonsway D, Rasheed JK, Biddle JW, McGowan JE Jr, Hanna B: Carbapenem resistance in Klebsiella pneumoniae not detected by automated susceptibility testing. Emerg Infect Dis 2006, 12:12091213.

71. Marchiaro P, Ballerini V, Spalding T, Cera G, Mussi MA, MoránBarrio J, Vila AJ, Viale AM, Limansky AS: A convenient microbiological assay employing cell-free extracts for the rapid characterization of Gram-negative carbapenemase producers. J Antimicrob Chemother 2008, 62:336-344.

72. Anderson KF, Lonsway DR, Rasheed JK, Biddle J, Jensen B, McDougal LK, Carey RB, Thompson A, Stocker S, Limbago B Patel JB: Evaluation of methods to identify the Klebsiella pneumoniae carbapenemase in Enterobacteriaceae. J Clin Microbiol 2007, 45:2723-2725.

73. Soothill JS, Lock PE: Screening for carbapenem-resistant bacteria. Lancet Infect Dis 2005, 5:597-598.

74. Parthasarathy $P$, Soothill J: A new screening method for carbapenem-resistant Acinetobacter baumanii and Pseudomonas aeruginosa. J Hosp Infect 2005, 61:357-358.

75. Levin AS, Levy CE, Manrique AE, Medeiros EA, Costa SF: Severe nosocomial infections with imipenem-resistant Acinetobacter baumannii treated with ampicillin/sulbactam. Int J Antimicrob Agents 2003, 21:58-62.

76. Russo TA: Diseases caused by Gram-negative enteric bacilli. In Harrison's Principles of Internal Medicine. 16th edition. Edited by Kaspar DL, Fauci AS, Longo DL, Braunwald E, Hauser SL, Jameson JL. New York: McGraw-Hill; 2005:878-885.

77. Kollef $\mathrm{MH}$, Fraser $\mathrm{VJ}$ : Antibiotic resistance in the intensive care unit. Ann Intern Med 2001, 134:298-314.

78. Lepper PM, Grusa E, Reichl H, Hogel J, Trautmann M: Consumption of imipenem correlates with beta-lactam resistance in Pseudomonas aeruginosa. Antimicrob Agents Chemother 2002, 46:2920-2925

79. Rahal JJ, Urban C, Horn D, Freeman K, Segal-Maurer S, Maurer J, Mariano N, Marks S, Burns JM, Dominick D, Lim M: Class restriction of cephalosporin use to control total cephalosporin resistance in nosocomial Klebsiella. JAMA 1998, 280:1233-1237.

80. Patzer JA, Dzierzanowska D: Increase of imipenem resistance among Pseudomonas aeruginosa isolates from a Polish paediatric hospital (1993-2002). Int J Antimicrob Agents 2007, 29: 153-158.

81. Fish DN, Teitelbaum I, Abraham E: Pharmacokinetics and pharmacodynamics of imipenem during continuous renal replacement therapy in critically ill patients. Antimicrob Agents Chemother 2005, 49:2421-2428.

82. Turnidge JD: The pharmacodynamics of beta-lactams. Clin Infect Dis 1998, 27:10-22.

83. Signs SA, Tan JS, Salstrom SJ, File TM: Pharmacokinetics of imipenem in serum and skin window fluid in healthy adults after intramuscular or intravenous administration. Antimicrob Agents Chemother 1992, 36:1400-1403.

84. Alvan G, Nord CE: Adverse effects of monobactams and carbapenems. Drug Saf 1995, 12:305-313.

85. Medical Letter. Imipenem-cilastatin sodium (Primaxin). Med Lett Drugs Ther 1986, 28:29-31.

86. Burkhardt O, Kumar V, Katterwe D, Majcher-Peszynska J, Drewelow B, Derendorf $H$, Welte T: Ertapenem in critically ill patients with early-onset ventilator-associated pneumonia: pharmacokinetics with special consideration of free-drug concentration. J Antimicrob Chemother 2007, 59:277-284.

87. Kwon KT, Oh WS, Song JH, Chang HH, Jung SI, Kim SW, Ryu SY, Heo ST, Jung DS, Rhee JY, Shin SY, Ko KS, Peck KR, Lee NY: Impact of imipenem resistance on mortality in patients with Acinetobacter bacteraemia. I Antimicrob Chemother 2007, 59:525-530. 
88. Tacconelli E, Tumbarello M, Bertagnolio S, Citton R, Spanu T, Fadda G, Cauda R: Multidrug-resistant Pseudomonas aeruginosa bloodstream infections: analysis of trends in prevalence and epidemiology. Emerg Infect Dis 2002, 8:220-221.

89. Harris A, Torres-Viera C, Venkataraman L, DeGirolami P, Samore M, Carmeli Y: Epidemiology and clinical outcomes of patients with multiresistant Pseudomonas aeruginosa. Clin Infect Dis 1999, 28:1128-1133.

90. Mikolajczyk RT, Sagel U, Bornemann R, Kramer A, Kretzschmar M: A statistical method for estimating the proportion of cases resulting from cross-transmission of multi-resistant pathogens in an intensive care unit. $J$ Hosp Infect 2007, 65:149-155.

91. Landman D, Quale JM, Mayorga D, Adedeji A, Vangala K, Ravishankar J, Flores C, Brooks S: Citywide clonal outbreak of multiresistant Acinetobacter baumannii and Pseudomonas aeruginosa in Brooklyn, NY: the preantibiotic era has returned. Arch Intern Med 2002, 162:1515-1520.

92. Chastre J, Wunderink R, Prokocimer P, Lee M, Kaniga K, Friedland I: Efficacy and safety of intravenous infusion of doripenem versus imipenem in ventilator-associated pneumonia: a multicenter, randomized study. Crit Care Med 2008, 36:1089-1096.

93. Jaruratanasirikul S, Sriwiriyajan S, Punyo J: Comparison of the pharmacodynamics of meropenem in patients with ventilatorassociated pneumonia following administration by 3-hour infusion or bolus injection. Antimicrob Agents Chemother 2005, 49:1337-1339.

94. Winston DJ, Lazarus HM, Beveridge RA, Hathorn JW, Gucalp R, Ramphal R, Chow AW, Ho WG, Horn R, Feld R, Louie TJ, Territo MC, Blumer JL, Tack KJ: Randomized, double-blind, multicenter trial comparing clinafloxacin with imipenem as empirical monotherapy for febrile granulocytopenic patients. Clin Infect Dis 2001, 32:381-390.

95. Slama TG, Amin A, Brunton SA, File TM Jr, Milkovich G, Rodvold KA, Sahm DF, Varon J, Weiland D Jr: A clinician's guide to the appropriate and accurate use of antibiotics: the Council for Appropriate and Rational Antibiotic Therapy (CARAT) criteria. Am J Med 2005, 118(Suppl 7A):1S-6S.

96. Sieger B, Berman SJ, Geckler RW, Farkas SA: Empiric treatment of hospital-acquired lower respiratory tract infections with meropenem or ceftazidime with tobramycin: a randomized study. Meropenem Lower Respiratory Infection Group. Crit Care Med 1997; 25:1663-1670. 